\title{
Effect of stress doses of hydrocortisone on S-100B vs. interleukin-8 and polymorphonuclear elastase levels in human septic shock
}

\author{
Thomas Mussack ${ }^{1, *}$, Josef Briegel ${ }^{2}$, Gustav \\ Schelling ${ }^{2}$, Peter Biberthaler ${ }^{1}$ and Marianne \\ Jochum ${ }^{3}$ \\ ${ }^{1}$ Department of Surgery Innenstadt, \\ ${ }^{2}$ Department of Anesthesiology Großhadern, \\ ${ }^{3}$ Department of Clinical Chemistry and Clinical \\ Biochemistry Innenstadt, \\ Klinikum der Universität München, Munich, \\ Germany
}

\begin{abstract}
Stress doses of hydrocortisone are known to have immunomodulatory effects in patients with hyperdynamic septic shock. The prognosis correlates with the presence and severity of septic encephalopathy. However, neurological evaluation is influenced by the use of analgesia sedation during artificial ventilation. The objective of this study was to demonstrate the effect of stress doses of hydrocortisone during the initial phase of human septic shock on the serum values of the neurospecific protein S-100B in comparison to the inflammation markers interleukin (IL)-8 in serum and polymorphonuclear (PMN) elastase in plasma. A total of 24 consecutive patients, who met the American College of Chest Physicians/Society of Critical Care Medicine criteria for septic shock, were enrolled in this prospective, randomized, double-blind, singlecenter trial. The severity of illness at recruitment was graded using the Acute Physiology and Chronic Health Evaluation II and the Simplified Acute Physiology Score II scoring systems. Multi-organ dysfunction syndrome was described by the Sepsis-related Organ Failure Assessment (SOFA) score. All patients were prospectively randomized to receive either stress doses of hydrocortisone or placebo. Hydrocortisone was started in 12 patients with a loading dose of $100 \mathrm{mg}$ and followed by a continuous infusion of $0.18 \mathrm{mg} / \mathrm{kg} / \mathrm{h}$ for 6 days. Median S-100B serum levels of the hydrocortisone group decreased from 0.32 $\mathrm{ng} / \mathrm{mL}$ at study entry to $0.07 \mathrm{ng} / \mathrm{mL} 6$ days later without significant differences compared to the placebo group. Initial IL-8 serum levels were significantly higher in the hydrocortisone group up to $12 \mathrm{~h}$ after study entry, and significantly decreased from 715 to 17 $\mathrm{pg} / \mathrm{mL}$ at the end of the observation period. Median PMN elastase plasma levels were not affected by hydrocortisone infusion. Patients with initial S-100B
\end{abstract}

*Corresponding author: Thomas Mussack, MD, Department of Surgery Innenstadt, Klinikum der Universität München, Nussbaumstraße 20, 80336 München, Germany Phone: + 49-89-5160-2638, Fax: + 49-89-5160-4489, E-mail: thomas.mussack@med.uni-muenchen.de serum levels $>0.50 \mathrm{ng} / \mathrm{mL}$ revealed significantly higher SOFA scores up to $30 \mathrm{~h}, \mathrm{IL}-8$ serum levels up to $12 \mathrm{~h}$, and PMN elastase plasma levels up to $36 \mathrm{~h}$ after study entry than those patients with $\leq 0.50 \mathrm{ng} / \mathrm{mL}$. These effects were independent of the amount of fluid correction for hemodilution. Starting S-100B, IL-8 and PMN elastase values of the hydrocortisone group were within the ranges already known in patients with out-of-hospital cardiac arrest or severe traumatic brain injury. Stress doses of hydrocortisone resulted in a significant reduction in IL-8 serum, but not in S$100 \mathrm{~B}$ serum and PMN elastase plasma concentrations in patients with hyperdynamic septic shock. For the first time, a similar extent of S-100B increase in serum of septic patients at the time of diagnosis was shown as reported for cardiac arrest or severe traumatic brain injury.

Keywords: cerebral ischemia; hydrocortisone; inflammation; septic shock; S-100B.

\section{Introduction}

The endogenous glucocorticoid hydrocortisone plays a pivotal role in modulation of the immune response to sepsis (1). Low-dose hydrocortisone infusions may attenuate this systemic inflammatory response, as judged by clinical signs and inflammatory markers (2-4). Two double-blind, single-center trials demonstrated that stress doses of hydrocortisone reversed septic shock, as defined by cessation of vasopressor therapy. The earlier weaning from vasopressor therapy in septic shock was associated with improvements in organ dysfunction and mortality rates $(5,6)$.

Apart from failure of many vital parenchymal organs, critical illness myopathy or dysfunction of peripheral nerves, septic shock may cause serious brain damage and septic encephalopathy (7-10). Septic encephalopathy represents a multifocal or diffuse cerebral malfunction, which may occur in the context of a systemic infection without direct traumatic affection of the brain (11-14). The prognosis for septic patients clearly correlates with the presence and severity of encephalopathy. Mortality in patients without encephalopathy varies between $0 \%$ and $26 \%$ (11) and amounts to nearly $50 \%$ in patients with severe symptoms of encephalopathy. Although the severity of the systemic infection seems to be responsible for the high mortality rate rather than the encephalopathy itself, an increase in mortality rate was reported in relation to the Glasgow-Coma-Scale (GCS) score in 50 patients with septic encephalopathy (14). This 
score is still used for the evaluation of neurological dysfunction and prognosis throughout the course of multi-organ failure (MOF) $(15,16)$. However, since determination of the GCS score in septic shock is clearly influenced by the use of analgesia sedation during artificial ventilation, the evaluation of a reliable biochemical marker, which could supply evidence for encephalopathy in the initial phase of sepsis and before the occurrence of clinically leading symptoms, seems meaningful.

Measurement of the neuroprotein S-100B released into the circulation was considered as a reliable procedure in detecting brain damage due to isolated traumatic brain injury (17), stroke (18), hemorrhage (19) or global ischemia $(20,21)$. Increased S-100B serum levels have also been observed to correlate with the duration of cardiopulmonary bypass surgery (22) and the associated development of neurological complications $(23,24)$. S-100B is physiologically localized in the cytosol or bound to the membranes of astroglial cells, mostly of the central nervous system (25). If these cells are damaged, S-100B is rapidly released, leaking into the cerebrospinal fluid and secondarily across the blood-brain barrier into the circulation. The protein is eliminated by the kidney with a biological half-life between 30 and $113 \mathrm{~min}(26,27)$. Continuously increasing S-100B serum levels after brain injury may reflect both early cellular damage due to impaired permeability of the blood-brain barrier (24) and delayed renal elimination.

The objective of our study, which was part of a double-blind trial, was to analyze the effect of stress doses of hydrocortisone on circulating S-100B as a possible measure of neurological dysfunction in patients during the initial phase of hyperdynamic septic shock, and to compare these results with the profile of two well-known inflammation parameters [interleukin-8 (IL-8) and polymorphonuclear (PMN) elastase] in the circulation.

\section{Materials and methods}

\section{Study design and subjects}

The study protocol was approved by the institutional Review Board of the Ludwig-Maximilians-University of Munich. Relatives of the patients were informed regarding the medical problems, as well as the nature and purpose of the study, and served as surrogates to determine the judgment of unconscious patients with respect to participation in the study. The study was conducted in the multidisciplinary intensive care unit (ICU) of the Department of Anesthesiology Munich-Grosshadern in the university hospital.

Patients suffering from septic shock were prospectively enrolled if they were on vasopressor support and met the criteria for septic shock proposed by the members of the American College of Chest Physicians (ACCP)/Society of Critical Care Medicine (SCCM) Consensus Conference Committee (28): documented infection or positive blood culture; at least two symptoms of the systemic inflammatory response syndrome, such as fever (body temperature $>38^{\circ} \mathrm{C}$ ) or hypothermia (body temperature $<36^{\circ} \mathrm{C}$ ), tachycardia ( $>90$ beats/ $\mathrm{min})$, tachypnea ( $>20$ breaths $/ \mathrm{min})$ or hyperventilation
$\left[\mathrm{PaCO}_{2}<32\right.$ torr $\left.(4.33 \mathrm{kPa})\right]$, and abnormal white blood cell counts $\left[>12,000\right.$ cells $/ \mathrm{mm}^{3}$ or $<4,000$ cells $/ \mathrm{mm}^{3}$ or immature neutrophils (bands $>10 \%$ )] evidence of organ dysfunction or hypoperfusion abnormality; and persistent sepsis-induced hypotension despite adequate fluid resuscitation or the use of inotropic or vasopressor support.

Fluid resuscitation was considered to be adequate when the pulmonary capillary wedge pressure (PCWP) reached values between 12 and $15 \mathrm{~mm} \mathrm{Hg}$. Referring to the SCCM guidelines, only patients on vasopressor support and with high-output circulatory failure defined by a cardiac index $(\mathrm{Cl})$ $>4.0 \mathrm{~L} / \mathrm{min} / \mathrm{m}^{2}$ (in patients $>55$ years, $>3.5 \mathrm{~L} / \mathrm{min} / \mathrm{m}^{2}$ due to reduced cardiac output with age) were randomized to the treatment groups. The hypercirculatory state had to be present without the use of positive inotropic agents such as dobutamine, dopexamine or epinephrine. Patients who were treated with vasopressors for $>72 \mathrm{~h}$ or with glucocorticoids were not included. The definition of the target population was based on data from a pilot study (29); the study design and patient treatment routine have already been described (5).

Vasopressor therapy was titrated to achieve a mean arterial pressure (MAP) of $>70 \mathrm{~mm} \mathrm{Hg}$. If dopamine exceeded a dose of $10 \mu \mathrm{g} / \mathrm{kg} / \mathrm{min}$, norepinephrine combined with dopamine in low dose $(2-4 \mu \mathrm{g} / \mathrm{kg} / \mathrm{min})$ was the proposed drug option. After randomization, however, the attending physicians were free to use additional catecholamines such as epinephrine, dobutamine, or dopexamine. When septic shock reversed, norepinephrine or epinephrine was tapered off in steps of $0.02-0.03 \mu \mathrm{g} / \mathrm{kg} / \mathrm{min}$ (5).

Infections were diagnosed according to clinical and microbiological criteria. Suspected infection at the time of enrolment was proven by clinical or microbiological examination. Bacterial infections were treated with selective antibiotic regimens, with preference given to third-generation cephalosporins, the carbapenem imipenem-cilastin, or the quinolone ciprofloxacin. Bacterial and fungal cultures (respiratory secretions, urine, peritoneal fluid, and wound swabs) were routinely assayed on fixed days twice each week. In addition, swabs of the peritoneum were taken from each quadrant of the abdomen in cases of surgery. In cases of new or unexplained fever $\left(>38.5^{\circ} \mathrm{C}\right)$, two blood cultures were taken by intravenous puncture, and all venous and arterial catheters were changed. The tips of all catheters were examined for colonies of bacteria or fungi. Bronchoscopy with bronchoalveolar lavage and protected-brush specimens was carried out in cases of new pulmonary infiltrates indicated on the chest radiograph. Selective decontamination of the nasooropharynx and the digestive tract was performed throughout the period spent in the ICU using a regimen of polymyxin B (50 mg every $6 \mathrm{~h}$ ) and gentamicin ( $80 \mathrm{mg}$ every $6 \mathrm{~h}$ ) dissolved in $10 \mathrm{~mL}$ of $0.9 \%$ saline. A $1-\mathrm{mL}$ aliquot of this solution was instilled into each nostril, $3 \mathrm{~mL}$ into the oropharynx, and $5 \mathrm{~mL}$ via a nasogastric tube into the stomach (5).

The severity of illness at the time of enrolment was determined using the Acute Physiology and Chronic Health Evaluation (APACHE) II and III, and Simplified Acute Physiology scoring (SAPS) systems. The primary study endpoint was the time to shock reversal, as defined by cessation of vasopressor support. Secondary endpoints were hyperdynamic alteration, multiple-organ dysfunction syndrome, systemic inflammatory response, and evolution of coagulation disorders (5).

During controlled ventilation and treatment with antibiotics, infusions, and systemic vasopressor support in the ICU, anesthesia aimed at a constant GCS score of 3 points was achieved by titration of midazolam and fentanyl. Therefore, the neurological investigation had to be limited to the exam- 
ination of reflexes. When the sedative drugs were reduced, the actual GCS score was recorded, using the grading proposed for patients on mechanical ventilation (30). The Sepsis-related Organ Failure Assessment (SOFA) score, which was published in 1996 (31), was added to the study protocol by amendment and retrospectively calculated from the raw data.

\section{Interventions}

A total of 24 patients were prospectively randomized to receive infusions of either stress doses of hydrocortisone $(n=12)$ or placebo $(n=12)$. Hydrocortisone administration was started with a loading dose of $100 \mathrm{mg}$, administered intravenously in $30 \mathrm{~min}$, followed by continuous infusion of $0.18 \mathrm{mg} / \mathrm{kg} / \mathrm{h}$. According to the SCCM guidelines, either continuous infusion of 200-300 mg hydrocortisone/day for 7 days with subsequent dose reduction, or low-dose application of 50-75 mg hydrocortisone four times a day is recommended for the management of patients with septic shock (32). After reversal of septic shock (defined as dopamine doses of $<6 \mu \mathrm{g} / \mathrm{kg} / \mathrm{min}$ or cessation of norepinephrine/ epinephrine infusion) the dose of hydrocortisone was reduced to $0.08 \mathrm{mg} / \mathrm{kg} / \mathrm{h}$. This dose was kept constant for 6 days. As soon as the underlying infection had been treated successfully or the sodium serum concentrations had increased to $>155 \mathrm{mmol} / \mathrm{L}$, the hydrocortisone infusion was tapered off in steps of $24 \mathrm{mg} /$ day. Physiological saline solution was used as placebo. To conduct the study in a doubleblind manner, the study drugs were prepared by research assistants at our institution, who were not involved in the study or in the clinical care of the patients. Study drug preparation has been already described (5).

For continuous venovenous hemofiltration (CVVH; $n=10$ ) blood was taken from the subclavian, internal jugular, or femoral vein, and a blood pump was used to perfuse the filtration membrane. The dialysate compartment of the membrane unit was under negative pressure relative to the blood compartment, which permitted hydraulic ultrafiltration of excess fluid across the membrane. Dialyzed blood was returned to the patient through tubing with an air embolus protector. To prevent clotting in the extracorporeal circuit, heparin was given to produce full systemic anticoagulation (whole blood clotting time $>30 \mathrm{~min}$ ). Anticoagulation was permanently monitored, and the heparin dose was subsequently individualized.

\section{Blood sampling and biochemical measurements}

The first blood samples were taken at study entry in the ICU [point of measurement (PM)1]. Subsequently, blood samples were drawn every $6 \mathrm{~h}$ (PM2-9) during the next 2 days, and once a day throughout the following 4 days (PM10-13). All specimens were converted to serum or citrated plasma, centrifuged with $3000 \mathrm{U} / \mathrm{min}$ for $10 \mathrm{~min}$ at room temperature, and frozen in aliquots at $-70^{\circ} \mathrm{C}$ until batch evaluation.

S-100B serum levels were analyzed by means of an immunoluminometric assay (LIAMAT ${ }^{\circledR}$ Sangtec $^{\circledR} 100$; Byk-Sangtec Diagnostica, Dietzenbach, Germany) with a lower detection limit of $0.02 \mathrm{ng} / \mathrm{mL}$ and a cut-off level of $<0.12 \mathrm{ng} / \mathrm{mL}$ for normal values. IL-8 serum values were determined using a quantitative ELISA (IL-8 Milenia; Milenia Biotec, Bad Nauheim, Germany) with a detection limit of $0.5 \mathrm{pg} / \mathrm{mL}$ and a normal range of $0-30 \mathrm{pg} / \mathrm{mL}$. Plasma levels of PMN elastase complexed with $\alpha_{1}$-proteinase inhibitor were quantified by means of a specific two-site ELISA (PMN Elastase Milenia; Milenia Biotec; normal values 19-78 ng/mL).
Total serum protein concentrations were measured with a specific microprotein assay kit (Micro BCA Protein Assay; Pierce, Rockford, IL, USA) in order to avoid interferences with possible hemodilution. Due to logistic reasons (limited sample size) we had to use the BCA assay instead of the Biuret total protein assay. In addition, the C-reactive protein (CRP) serum levels ( $\mathrm{mg} / \mathrm{dL}$ ), as well as the creatinine serum levels $(\mathrm{mg} / \mathrm{dL})$ and fluid balance $(\mathrm{mL})$ per $24 \mathrm{~h}$ were calculated to identify the amount of fluid correction for hemodilution.

\section{Statistical analysis}

All demographic and biochemical data are presented as median and interquartile range (IQR; 25th-75th percentile). Group differences at each point of measurement were accomplished by means of a Mann-Whitney U-test or Wilcoxon test due to non-normal distribution of the data. The Kaplan-Meier method was used to determine the probability of being on vasopressor therapy over time. The failure times until cessation of vasopressor therapy were compared using a generalized Wilcoxon (Breslow) test.

The entire study group was differentiated into subgroups $1(>0.50 \mathrm{ng} / \mathrm{mL})$ and $2(\leq 0.50 \mathrm{ng} / \mathrm{mL})$ with respect to $\mathrm{S}-100 \mathrm{~B}$ levels at study entry. Biochemical data for septic patients were compared to those reported for patients with out-ofhospital cardiac arrest or isolated severe traumatic brain injury (GCS score $\leq 8$ points), and healthy volunteers without a history of brain or cardiac damage $(17,21,33)$. Blood sampling of the control groups was carried out after informed consent. The statistical analysis was performed using SPSS version 12.0 (SPSS GmbH Software, Munich, Germany), and a two-tailed p-value of $<0.05$ was considered to be significant.

\section{Results}

\section{Demographic and clinical characteristics of the study groups}

A total of 12 patients were assigned each to the therapy group receiving stress doses of hydrocortisone $(\mathrm{H})$ and to the placebo (P) group, respectively (5). The characteristics of both patient groups did not differ according to demographic data, severity of the illness and the degree of organ dysfunction (Table 1). In addition, no significant differences occurred concerning CVVH application, length of artificial ventilation and survival rate after 28 days between the groups.

Shock reversal was achieved in 11 of the 12 patients treated with hydrocortisone vs. 9 of the 12 patients treated with placebo. The median time of vasopressor support in group $\mathrm{H}$ [2 days (IQR 1-6)] was significantly reduced compared to group P [7 days (3-19); Figure 1]. Specific analysis revealed significant increases in terms of mean arterial pressure and systemic vascular resistance, and showed a trend to earlier resolution of the organ dysfunction syndrome in group $\mathrm{H}(5)$.

No differences were evident between the groups regarding the type and anatomical site of the underlying infection. The primary cause of septic shock was peritonitis in 9 patients ( 4 in group $H, 5$ in group P) 
Table 1 Characteristics of septic shock patients randomized into hydrocortisone $(n=12)$ and placebo $(n=12)$ groups.

\begin{tabular}{|c|c|c|c|}
\hline \multirow{2}{*}{ Characteristic } & \multicolumn{2}{|l|}{ Group } & \multirow[t]{2}{*}{$p$} \\
\hline & $\begin{array}{l}\text { Hydrocortisone } \\
(\mathrm{n}=12)\end{array}$ & $\begin{array}{l}\text { Placebo } \\
(n=12)\end{array}$ & \\
\hline Age, years & $41(30-65)$ & $54(47-57)$ & 0.410 \\
\hline Male, \% & 58 & 50 & 0.755 \\
\hline APACHE II score, points & $25(20-28)$ & $28(18-32)$ & 0.590 \\
\hline APACHE III score, points & $85(71-104)$ & $85(53-112)$ & 0.671 \\
\hline SAPS II score, points & $53(46-60)$ & $48(42-76)$ & 0.630 \\
\hline CVVH, \% & 42 & 42 & 1.000 \\
\hline Length of ventilation, days & $16(12-24)$ & $21(8-38)$ & 0.755 \\
\hline Mortality rate, \% & 25 & 42 & 0.514 \\
\hline \multicolumn{4}{|l|}{ Primary cause of sepsis } \\
\hline Peritonitis, \% & 33 & 42 & 0.466 \\
\hline Pneumonia, \% & 58 & 50 & 0.755 \\
\hline \multicolumn{4}{|l|}{ Baseline values } \\
\hline $\mathrm{S}-100 \mathrm{~B}, \mathrm{ng} / \mathrm{mL}$ & $0.32(0.19-3.60)$ & $0.41(0.18-0.70)$ & 0.062 \\
\hline IL-8, pg/mL & $715(156-6275)$ & $94(68-948)$ & $<0.010^{*}$ \\
\hline PMN elastase, $\mathrm{ng} / \mathrm{mL}$ & $637(496-1680)$ & $522(173-674)$ & 0.058 \\
\hline $\mathrm{CRP}, \mathrm{mg} / \mathrm{dL}$ & $25(22-33)$ & $19(13-36)$ & 0.148 \\
\hline Creatinine, mg/dL & $1.2(0.8-2.3)$ & $1.0(0.7-1.8)$ & 0.563 \\
\hline Fluid balance, $\mathrm{mL}$ & $2200(25-4188)$ & $2500(580-4025$ & 0.870 \\
\hline
\end{tabular}

Age, scores and days of ventilation are presented as median and interquartile range $\left(25 \%-75 \%\right.$ percentile). ${ }^{*}$ Significant difference between groups in the Mann-Whitney U-test.

and pneumonia in 13 patients ( 7 in group $H, 6$ in group $\mathrm{P})$. In all nine subjects, peritonitis required at least one surgical intervention, which was applied in a timely manner, in most cases immediately after study entry. One patient each suffered from meningitis and severe soft tissue infection, respectively. The initial antibiotic treatment was inadequate in seven patients ( 3 in group $\mathrm{H}, 4$ in group $\mathrm{P}$ ) and was corrected according to the results of the microbiological examinations.

\section{S-100B/IL-8 serum and PMN elastase plasma levels after randomization in hydrocortisone or placebo group}

Baseline median S-100B, IL-8, and PMN elastase levels were considerably elevated for both groups com-

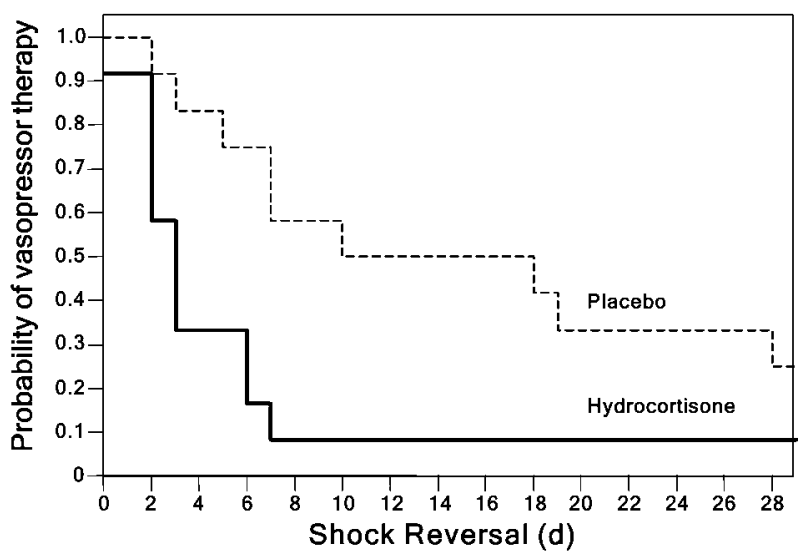

Figure 1 Kaplan-Meier curves showing the probability of being on vasopressor therapy during the course of the study. Comparisons between the time distribution of both treatment groups were performed by means of generalized Wilcoxon (Breslow) test; $\mathrm{p}=0.006$. pared to values for healthy individuals (Figure 2). After hydrocortisone infusion, only median serum concentrations of IL-8 decreased significantly from $715 \mathrm{pg} / \mathrm{mL}(156-6275 \mathrm{pg} / \mathrm{mL})$ to $17 \mathrm{pg} / \mathrm{mL}(12-32$ $\mathrm{pg} / \mathrm{mL}$ ) at the end of the observation period, reaching the normal range by $18 \mathrm{~h}$ after study entry $[28 \mathrm{pg} / \mathrm{mL}$ (16-121 pg/mL); PM4]. In contrast, S-100B serum and PMN elastase plasma levels in group $\mathrm{H}$ were not significantly affected over time (Figure 2). Similarly, serum concentrations of S-100B and IL-8, as well as plasma concentrations of PMN elastase in group $\mathrm{P}$ did not significantly decrease during the observation period.

Median S-100B serum levels in group $\mathrm{H}$ decreased from $0.32 \mathrm{ng} / \mathrm{mL}(0.19-3.60 \mathrm{ng} / \mathrm{mL})$ at study entry to $0.07 \mathrm{ng} / \mathrm{mL}(0.04-0.32 \mathrm{ng} / \mathrm{mL}) 6$ days later, without significant differences compared to group P. Only S100B levels at PM3 (12 h after study entry) at 0.87 $\mathrm{ng} / \mathrm{mL}(0.14-2.63 \mathrm{ng} / \mathrm{mL})$ were significantly higher in group $\mathrm{H}$ compared to $0.37 \mathrm{ng} / \mathrm{mL}(0.14-0.77 \mathrm{ng} / \mathrm{mL}$ ) in group $\mathrm{P}$ (Figure 2). Initial median IL-8 serum levels in group $\mathrm{H}$ were significantly higher compared to group $P$ only from study entry $[715 \mathrm{pg} / \mathrm{mL}$ $(156-6275 \mathrm{pg} / \mathrm{mL})]$ until $12 \mathrm{~h}$ later $[49 \mathrm{pg} / \mathrm{mL}$ (33-428 pg/mL)]. Median PMN elastase plasma levels did not differ between the groups with time, although PMN elastase values from PM1 (study entry) to PM4 (18 $\mathrm{h}$ after study entry) were slightly higher in group $\mathrm{H}$ than in group $\mathrm{P}$ (Figure 2).

Median CRP serum values in both groups were significantly elevated compared to those in healthy individuals. Only median CRP levels in group $\mathrm{H}$ significantly decreased from $25(22-33)$ to $14(8-20)$ $\mathrm{mg} / \mathrm{dL} 3$ days after study entry (PM10) and to 7 (2-13) $\mathrm{mg} / \mathrm{dL}$ at the end of the observation period, but did not reach the normal range (Figure 2). Although CRP values in group $\mathrm{H}$ were slightly higher from PM1 (study entry) to PM8 (42 h after study entry), median 

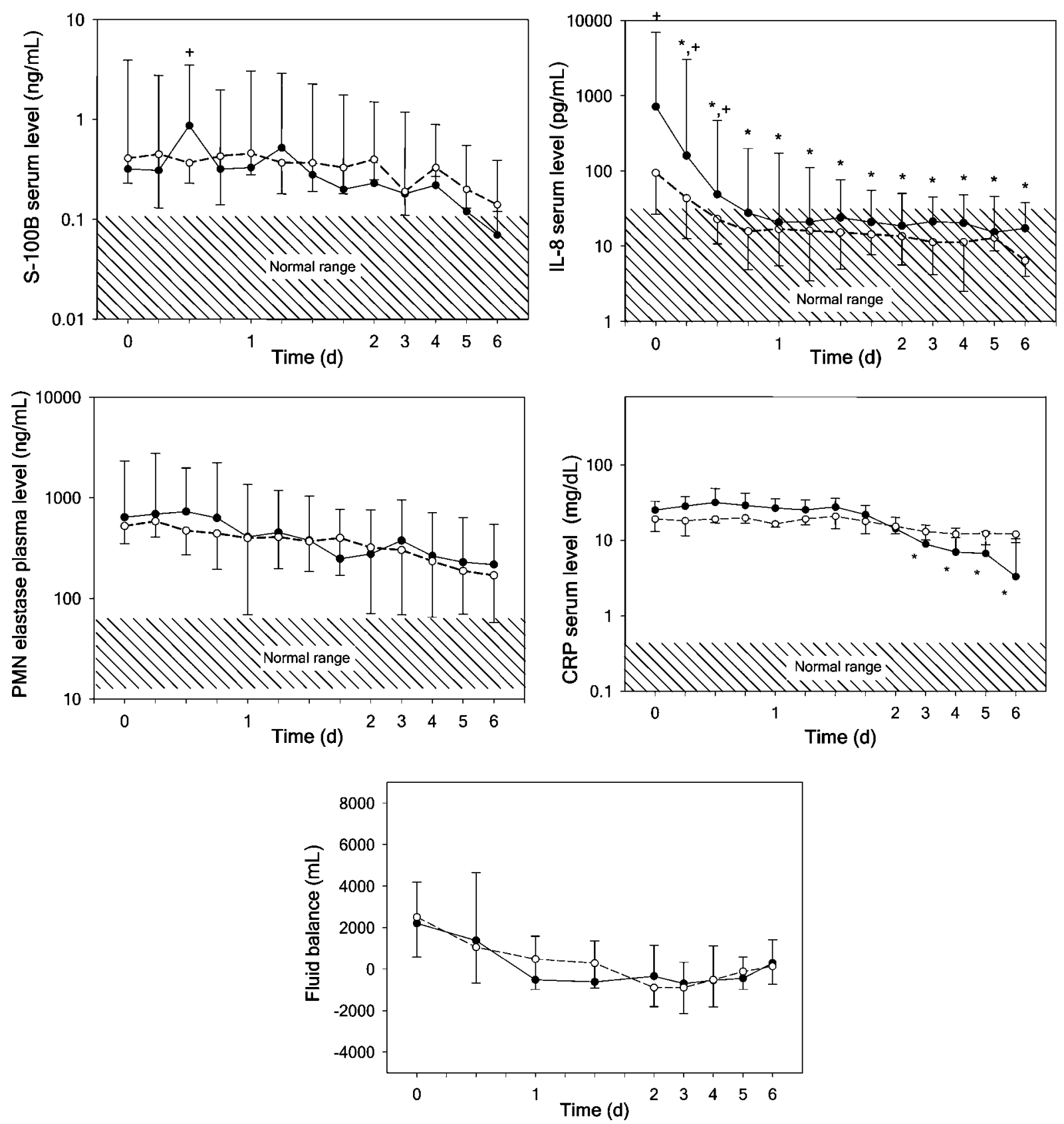

Figure 2 Serum S-100B, IL-8, and plasma PMN elastase levels, as well as serum CRP levels and fluid balance within the first 6 days of septic shock. Patients were randomized in the hydrocortisone group $(n=12 ; \bullet$; data are given as line and scatter plots presenting median and 75th percentile) or the placebo group $(n=12 ; 0$; data are given as line and scatter plots presenting median and 25th percentile). The upper normal value amounts to $0.12 \mathrm{ng} / \mathrm{mL}$ for S-100B, to $30 \mathrm{pg} / \mathrm{mL}$ for IL-8, to $78 \mathrm{ng} / \mathrm{mL}$ for PMN elastase and to $0.5 \mathrm{mg} / \mathrm{dL}$ for CRP. The first blood samples were taken at study entry at the ICU. Subsequent blood samples were drawn every $6 \mathrm{~h}$ during the next 2 days, and once a day throughout the following 4 days. $+\mathrm{p}<0.05$ represents significant group differences between the two randomized groups. ${ }^{*} p<0.05$ shows significant differences compared to the baseline levels at study entry.

serum CRP and fluid balance (Figure 2), as well as baseline creatinine levels, did not differ between the groups (Table 1).

\section{SOFA score, IL-8 serum and PMN elastase plasma levels depending on the initial S-100B serum levels}

As shown in Table 2, patients in subgroup $1(\mathrm{n}=8$; initial S-100B serum level $>0.50 \mathrm{ng} / \mathrm{mL}$ ) showed no statistical differences concerning age, gender, SAPS II score, or administration of hydrocortisone when compared to those in subgroup $2(n=16$; initial S-
$100 \mathrm{~B}$ serum level $\leq 0.50 \mathrm{ng} / \mathrm{mL}$ ). In contrast, the APACHE II and APACHE III score, CVVH application, days required for artificial ventilation, and mortality rate after 28 days were significantly higher in subgroup 1 patients (Table 2).

The median S-100B serum levels in subgroup 1 were always significantly higher than in subgroup 2 (Figure 3). Interestingly, the initial, highly elevated $\mathrm{S}-100 \mathrm{~B}$ values in subgroup 1 of $2.60 \mathrm{ng} / \mathrm{mL}$ $(1.52-5.89 \mathrm{ng} / \mathrm{mL}$ ) were within the data ranges recently demonstrated for patients with out-of-hospital car- 
Table 2 Characteristics of septic shock patients with pathologically elevated initial S-100B serum levels $>0.50 \mathrm{ng} / \mathrm{mL}$ (subgroup 1) and $\leq 0.50 \mathrm{ng} / \mathrm{mL}$ (subgroup 2).

\begin{tabular}{llll}
\hline Characteristic & Subgroup & & \\
\cline { 2 - 4 } & $1(\mathrm{n}=8)$ & $2(\mathrm{n}=16)$ & 0.070 \\
\hline Age, years & $41(30-52)$ & $55(33-66)$ & 1.000 \\
Male, \% & 50 & 50 & $0.016^{*}$ \\
APACHE II score, points & $28(25-29)$ & $22(18-27)$ & $0.029^{*}$ \\
APACHE III score, points & $98(74-141)$ & $75(54-87)$ & 0.070 \\
SAPS II score, points & $65(46-89)$ & $48(42-54)$ & $0.020^{*}$ \\
CVVH, \% & 75 & 19 & $0.038^{*}$ \\
Length of ventilation, days & $24(14-32)$ & $14(6-20)$ & 0.482 \\
Hydrocortisone, \% & 63 & 44 & $0.046^{*}$ \\
Mortality rate, \% & 50 & 25 & \\
\hline
\end{tabular}

Age, scores and days of ventilation are presented as median and interquartile range (25th-75th percentile). ${ }^{*}$ Significant difference between groups in the Mann-Whitney U-test.

diac arrest or severe traumatic brain injury $(21,33)$. Furthermore, median S-100B serum levels in subgroup 2 decreased to $0.05 \mathrm{ng} / \mathrm{mL}(0.02-0.18 \mathrm{ng} / \mathrm{mL})$ at PM13, and were still elevated compared to the value for healthy controls of $0.04 \mathrm{ng} / \mathrm{mL}(0.01-0.08 \mathrm{ng} / \mathrm{mL})$ (17).

Patients in subgroup 1 showed higher median SOFA scores than those in subgroup 2 during the observation period, but the differences were significant only from PM1 to PM6 (Figure 3).

Subgroup 1 showed only significantly higher median IL-8 serum levels from PM1 to PM3 compared to subgroup 2. From PM4 to the end of the observation period, median IL-8 serum levels were similar in both subgroups, and ranged within standard values by $24 \mathrm{~h}$ after study entry (PM5). Highly increased PMN elastase values declined in both subgroups with time, but remained clearly elevated above the normal range at the end of the observation period. However, patients in subgroup 1 showed significant differences in PMN elastase plasma levels compared to subgroup 2 only from study entry (PM1) to $36 \mathrm{~h}$ later (PM7).

Median CRP serum values remained clearly elevated in both subgroups during the entire observation period. Only CRP levels in subgroup 2 significantly decreased from $25 \mathrm{mg} / \mathrm{dL}$ (18-41 mg/dL; PM1) to $14 \mathrm{mg} / \mathrm{dL}(9-21 \mathrm{mg} / \mathrm{dL}) 3$ days after study entry (PM10) and to $9 \mathrm{mg} / \mathrm{dL}(5-13 \mathrm{mg} / \mathrm{dL}) 5$ days after study entry (PM12). However, median serum CRP and fluid balance did not differ between the subgroups (Figure 3).

\section{Discussion}

Clinical sequelae of hyperdynamic septic shock are organ dysfunction, such as mental disorders, disseminated intravascular coagulation, acute lung injury, renal failure, acute hepatic dysfunction, and cardiovascular dysfunction (31). The physiological function of hypercortisolemia associated with stress is to modulate the normal defense mechanisms, thus protecting the host from overactivation of inflammatory reactions (34). Cortisol interacts with the immune system at several levels, exerting suppressive and permissive effects. In a dose-dependent manner, corticosteroids inhibit proinflammatory cytokine synthesis and cellular immunity (35).

Since we observed mineralocorticoid effects of hydrocortisone infusion by measuring serum sodium and potassium concentrations, mineralocorticoids were not added to the treatment (5). Stress levels of cortisol increase sodium retention and produce hypertension in healthy humans. This effect is mediated by Type I and Type IV corticoid receptors (36). The increase in sodium concentrations in the hydrocortisone-treated group in this study suggests that mineralocorticoid effects of hydrocortisone contribute to improved vasopressor response (5).

One major finding of this study is that hydrocortisone administered in stress doses selectively reduced circulating IL-8 serum levels, but not S-100B serum and PMN elastase plasma levels in patients with hyperdynamic septic shock. This effect is obviously independent of the extent of fluid correction for hemodilution. Cytokines are peptides that primarily regulate the interaction and communication of cells of the immune system. In cases of infection, cytokines initiate the systemic inflammatory response by interacting with specific receptors on inflammatory target cells (1). IL-8, which is predominantly discharged from activated macrophages and endothelial cells into the circulation, represents an important chemoattractant for neutrophil granulocytes. During the whole-body inflammation in septic shock, these granulocytes release destructive superoxide anions and lysosomal enzymes such as PMN elastase upon activation (37-40). Since significant differences between patients receiving hydrocortisone or placebo were shown only for IL-8 serum concentrations compared to baseline levels, hydrocortisone does not seem to have a substantial influence on the release of PMN elastase in hyperdynamic septic shock.

However, the clinical data from this therapy study agree very well with results from other reports $(2,6)$. A significant improvement in the hemodynamic situation, i.e., an increase in mean arterial pressure and systemic vascular resistance, associated with a clear reduction of the need for catecholamines could be observed after application of stress doses of hydrocortisone instead of placebo (Figure 1). The reversal 

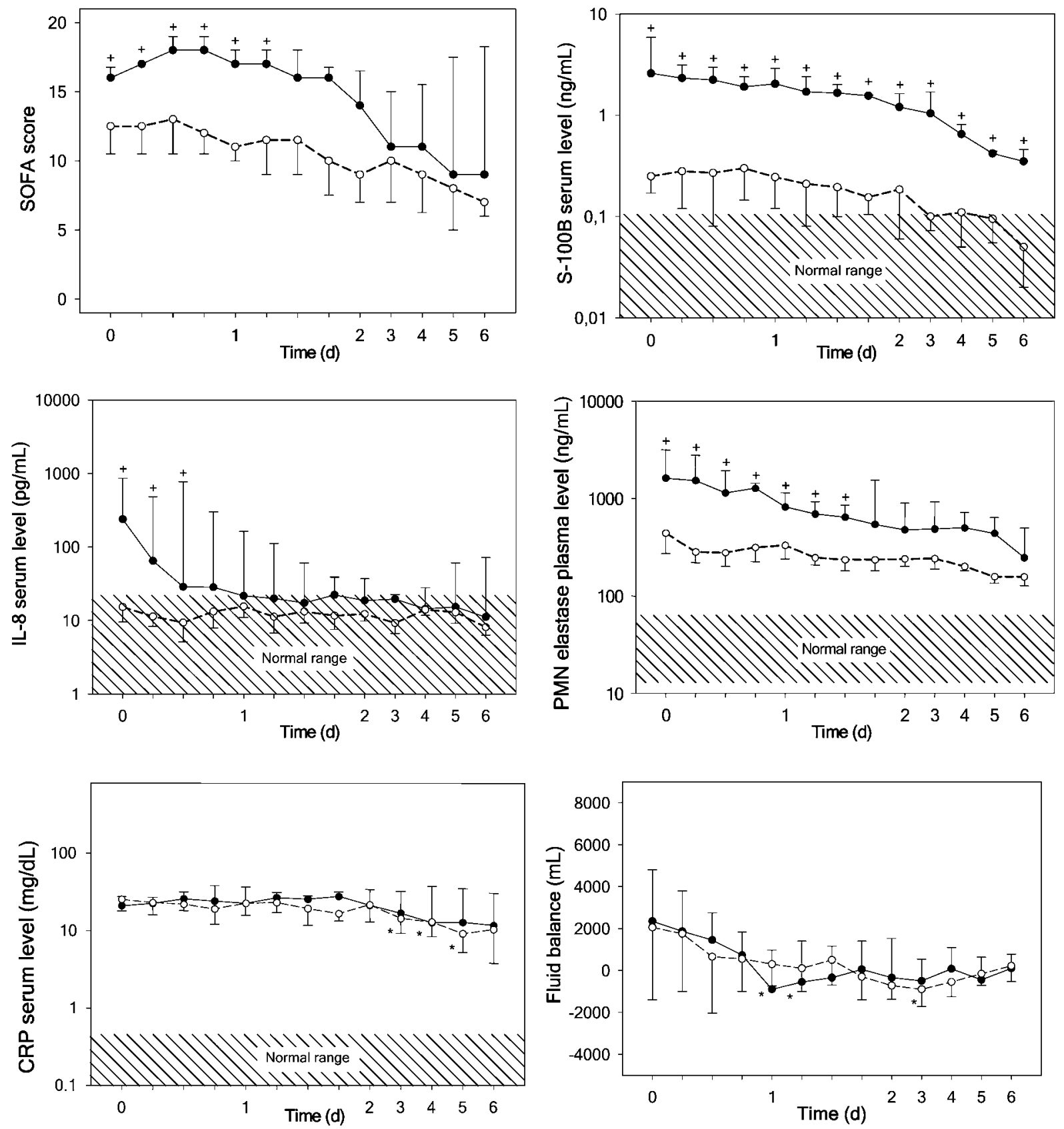

Figure 3 SOFA score, serum S-100B, IL-8, CRP, and plasma PMN elastase levels, as well as fluid balance within the first 6 days of septic shock. Patients were stratified in groups with an initial S-100B serum level $>0.50 \mathrm{ng} / \mathrm{mL}(\mathrm{n}=8 ; \bullet ;$ data are given as line and scatter plots presenting median and 75th percentile) or $\leq 0.50 \mathrm{ng} / \mathrm{mL}$ ( $\mathrm{n}=16$; $\circ$; data are given as line and scatter plots presenting median and 25 th percentile). $+p<0.05$ represents significant group differences between the two randomized groups.

of septic shock in the hydrocortisone group occurred more quickly than in the placebo group $(2,5,6)$. However, during the observation period of 6 days, no significant difference concerning a decrease in the originally highly elevated S-100B serum levels were apparent when using hydrocortisone compared to placebo.

The exact mechanisms that lead to similarly high S-100B serum concentrations, particularly in the initial phase of septic shock, as in patients with severe head injury are still unclear. Neuronal cells, as well as damaged fat and muscle cells, must be considered as possible sources for the release of S-100B (41-43).
Interestingly, patients with pathologically elevated initial S-100B serum levels of $>0.50 \mathrm{ng} / \mathrm{mL}$ showed significantly higher median SOFA scores up to $30 \mathrm{~h}$ after study entry than those patients with initial levels $\leq 0.50 \mathrm{ng} / \mathrm{mL}$. Moreover, individuals with clearly raised S-100B levels exhibited higher PMN elastase plasma levels until $36 \mathrm{~h}$, whereas their IL-8 serum levels were elevated only up to $12 \mathrm{~h}$ after study entry. Although impairment of astroglial cells, possibly leading to prolonged neurological dysfunction, cannot be excluded as the primary origin of S-100B in the circulation, the systemic inflammatory process and peripheral tissue damage also have to be taken into 
account as an additional cause for the different release pattern of S-100B protein $(25,41,44)$.

In critically ill patients with septic syndrome, disturbance of the neurological functions can arise from a multitude of origins. Patients may have head injuries due to accidental trauma or can be intoxicated. Furthermore, they may suffer from prolonged shock in the case of severe systemic infection and may need to be resuscitated under sedation analgesia because of vasogenic reactions, myocardial dysfunction or coagulation disturbances (45). Particularly in the early phase of the disease, septic encephalopathy is quite difficult to diagnose in patients with concomitant disturbance of kidney or liver function, with metabolic collapse or with endocrine abnormalities due to the similarity to cerebral dysfunctions of other origins.

The early form of septic encephalopathy, which may not yet be accompanied by MOF, but probably only by the release of pro- and anti-inflammatory cytokines and their cytotoxic effects, is different from the late form, which is usually combined with MOF, hypotension, and other systemic symptoms. Septic encephalopathy is clinically characterized by disturbances of concentration and disorientation, as well as by delirium and coma in heavy cases. Encephalopathy may precede the leading symptoms of sepsis, and may thus be of special diagnostic value as a possible early marker of subsequent organ system failures (11, $12,46)$. Radiological examinations, i.e., cerebral computed tomography (CCT), do not usually show any significant changes. Clinical evaluation can be achieved by means of electroencephalography (EEG) or the GCS score before sedation analgesia and intubation are applied.

The GCS score is frequently applied for the examination of cerebral dysfunctions. It correlates very well with the neurological long-term result in patients with severe head injuries, and can also be used for the evaluation of neurological dysfunctions in the longterm course of patients with $\operatorname{MOF}(15,16)$. Eidelman et al. (14) reported increased mortality in 50 patients with septic encephalopathy in relation to the GCS score $(16 \%$ at 15 points and $63 \%$ between 3 and 8 points). However, the clinical experience shows that the GCS score cannot always be estimated meaningfully in ICU patients with septic shock (30). Indeed, nearly all patients in our prospective randomized therapy study (5) were already sedated and ventilated for several days, and exhibited a continuous GCS score of 3 points when finally fulfilling the study entry criteria. Therefore, a valid neurological evaluation in the clinical process was practically impossible and the clinical diagnosis of septic encephalopathy would only have been possible by means of EEG. Yet, EEG was not typically applied due to the study design, for which measurements of S-100B serum levels were primarily not conceived (5).

In this situation, the introduction of a specific biochemical brain marker seemed to us to be of great interest for the retrospective diagnosis and prediction of septic encephalopathy in the long term. According to a recent study, the neuroprotein S-100B is expressed and released into the circulation not only in ischemic brain tissue damage after stroke or traumatic brain injury, but also during brain inflammation (47). Whether high local extracellular concentrations of S-100B have detrimental effects, such as the enhancement of apoptotic cell death, is still under debate (44). Therefore, we decided to evaluate S-100B serum levels in our patients with septic shock, whose serum samples were collected in the context of a prospective randomized study examining the effectiveness of hydrocortisone $(1,4,5)$.

Although our data reveal for the first time the similar extent of systemic S-100B release after septic shock as after out-of-hospital cardiac arrest or traumatic brain injury, the main limitation of this randomized controlled study is the small number of patients. From this it follows that the study may be underpowered with respect to the ability to identify any significant differences concerning age, days of ventilation or mortality rate.

\section{Conclusions}

Hypercortisolemia induced by the infusion of stress doses of hydrocortisone differentially regulates the response of the neuroprotein $\mathrm{S}-100 \mathrm{~B}$ and the inflammation markers IL-8 and PMN elastase in patients with hyperdynamic septic shock. In a randomized double-blind trial, we observed a significant reduction in IL-8 serum, but not in S-100B serum and PMN elastase plasma concentrations with time. For the first time, a similar extent of S-100B increase in serum of patients with septic shock at the time of primary diagnosis was shown as reported for out-of-hospital cardiac arrest or severe head injury. Although clinically relevant methods for judging brain damage in our septic shock patients are missing due to the study design, our data give clear hints for further prospective studies on S-100B serum levels in septic patients.

\section{Acknowledgements}

We thank Dr. Cornelia Gippner-Steppert, Mrs. Hell and Mrs. Maier, Department of Clinical Chemistry and Clinical Biochemistry, for their technical support. Moreover, we appreciate the statistical assistance of Stefan Moravec, Department of Surgery Innenstadt.

\section{References}

1. Briegel J, Jochum M, Gippner-Steppert C, Thiel M. Immunomodulation in septic shock: hydrocortisone differentially regulates cytokine responses. J Am Soc Nephrol 2001;12(Suppl 17):S70-4.

2. Keh D, Boehnke T, Weber-Cartens S, Schulz C, Ahlers O, Bercker $S$, et al. Immunologic and hemodynamic effects of "low-dose" hydrocortisone in septic shock: a doubleblind, randomized, placebo-controlled, crossover study. Am J Respir Crit Care Med 2003;167:512-20.

3. Briegel J, Kellermann W, Forst H, Haller M, Bittl M, Hoffmann GE, et al. Low-dose hydrocortisone infusion atten- 
uates the systemic inflammatory response syndrome. The Phospholipase A2 Study Group. Clin Invest 1994; 72:782-7.

4. Annane D, Sebille V, Charpentier C, Bollaert PE, Francois $B$, Korach JM, et al. Effect of treatment with low doses of hydrocortisone and fludrocortisone on mortality in patients with septic shock. J Am Med Assoc 2002;288:862-71.

5. Briegel J, Forst H, Haller M, Schelling G, Kilger E, Kuprat $\mathrm{G}$, et al. Stress doses of hydrocortisone reverse hyperdynamic septic shock: a prospective, randomized, double-blind, single-center study. Crit Care Med 1999;27: 723-32.

6. Bollaert PE, Charpentier C, Levy B, Debouverie M, Audibert G, Larcan A. Reversal of late septic shock with supraphysiologic doses of hydrocortisone. Crit Care Med 1998;26:645-50.

7. Wheeler AP, Bernard GR. Treating patients with severe sepsis. N Engl J Med 1999;340:207-14.

8. Bolton CF. Sepsis and the systemic inflammatory response syndrome: neuromuscular manifestations. Crit Care Med 1996;24:1408-16.

9. Hund E. Myopathy in critically ill patients. Crit Care Med 1999;27:2544-7.

10. Hund E. Neurological complications of sepsis: critical illness polyneuropathy and myopathy. J Neurol 2001; 248:929-34.

11. Young GB, Bolton CF, Austin TW, Archibald YM, Gonder J, Wells GA. The encephalopathy associated with septic illness. Clin Invest Med 1990;13:297-304.

12. Lindner A, Kappen K, Zierz S. Acute encephalopathy, polyneuropathy and myopathy in the critically ill patient. Internist (Berl) 1998;39:485-92.

13. Bolton CF, Young GB, Zochodne DW. The neurological complications of sepsis. Ann Neurol 1993;33:94-100.

14. Eidelman LA, Putterman D, Putterman C, Sprung CL. The spectrum of septic encephalopathy. Definitions, etiologies, and mortalities. J Am Med Assoc 1996;275:470-3.

15. Marshall JC, Cook DJ, Christou NV, Bernard GR, Sprung $\mathrm{CL}$, Sibbald WJ. Multiple organ dysfunction score: a reliable descriptor of a complex clinical outcome. Crit Care Med 1995;23:1638-52.

16. Barie PS, Hydo LJ, Fischer E. A prospective comparison of two multiple organ dysfunction/failure scoring systems for prediction of mortality in critical surgical illness. J Trauma 1994;37:660-6.

17. Mussack T, Biberthaler $P$, Wiedemann E, Kanz KG, Englert A, Gippner-Steppert C, et al. S-100b as a screening marker of the severity of minor head trauma (MHT) - a pilot study. Acta Neurochir Suppl 2000;76:393-6.

18. Wunderlich MT, Ebert AD, Kratz T, Goertler M, Jost S, Herrmann M. Early neurobehavioral outcome after stroke is related to release of neurobiochemical markers of brain damage. Stroke 1999;30:1190-5.

19. Wiesmann M, Missler U, Hagenstrom H, Gottmann D. S-100 protein plasma levels after aneurysmal subarachnoid haemorrhage. Acta Neurochir (Wien) 1997; 139:1155-60.

20. Rosen H. Increased serum levels of the S-100 protein are associated with hypoxic brain damage after cardiac arrest. Stroke 1998;29:473-7.

21. Mussack T, Biberthaler P, Gippner-Steppert C, Kanz KG, Wiedemann E, Mutschler W, et al. Early cellular brain damage and systemic inflammatory response after cardiopulmonary resuscitation or isolated severe head trauma: a comparative pilot study on common pathomechanisms. Resuscitation 2001;49:193-9.

22. Westaby S, Johnsson P, Parry AJ, Blomqvist S, Solem JO, Alling $C$, et al. Serum S100 protein: a potential marker for cerebral events during cardiopulmonary bypass. Ann Thorac Surg 1996;61:88-92.
23. Astudillo R, Van der Linden J, Radegran K, Hansson LO, Aberg B. Elevated serum levels of S-100 after deep hypothermic arrest correlate with duration of circulatory arrest. Eur J Cardiothorac Surg 1996;10:1107-12.

24. Blomquist $S$, Johnsson $P$, Luhrs $C$, Malmkvist $G$, Solem JO, Alling $C$, et al. The appearance of S-100 protein in serum during and immediately after cardiopulmonary bypass surgery: a possible marker for cerebral injury. $\mathrm{J}$ Cardiothorac Vasc Anesth 1997;11:699-703.

25. Haimoto H, Hosoda S, Kato K. Differential distribution of immunoreactive S100-alpha and S100-beta proteins in normal nonnervous human tissues. Lab Invest 1987; 57:489-98.

26. Jonsson $H$, Johnsson $P$, Hoglund $P$, Alling $C$, Blomquist $S$. Elimination of $\mathrm{S} 100 \mathrm{~B}$ and renal function after cardiac surgery. J Cardiothorac Vasc Anesth 2001;14:698-701.

27. Usui A, Kato K, Abe T, Murase M, Tanaka M, Takeuchi E. S-100ao protein in blood and urine during open-heart surgery. Clin Chem 1989;35:1942-4.

28. Bone RC, Balk RA, Cerra FB, Dellinger RP, Fein AM, Knaus WA, et al. Definitions for sepsis and organ failure and guidelines for the use of innovative therapies in sepsis. The ACCP/SCCM Consensus Conference Committee. American College of Chest Physicians/Society of Critical Care Medicine [see comments]. Chest 1992;101:1644-55.

29. Briegel J, Forst H, Hellinger H, Haller M. Contribution of cortisol deficiency to septic shock. Lancet 1991; 338:507-8.

30. Bastos PG, Sun X, Wagner DP, Wu AW, Knaus WA. Glasgow Coma Scale score in the evaluation of outcome in the intensive care unit: findings from the Acute Physiology and Chronic Health Evaluation III study. Crit Care Med 1993; $21: 1459-65$.

31. Vincent JL, Moreno R, Takala J, Willatts S, De Mendonca A, Bruining $H$, et al. The SOFA (Sepsis-related Organ Failure Assessment) score to describe organ dysfunction/failure. On behalf of the Working Group on SepsisRelated Problems of the European Society of Intensive Care Medicine. Intensive Care Med 1996;22:707-10.

32. Hollenberg SM, Ahrens TS, Annane D, Astiz ME, Chalfin DB, Dasta JF, et al. Practice parameters for hemodynamic support of sepsis in adult patients: 2004 update. Crit Care Med 2004;32:1928-48.

33. Herrmann M, Jost $S$, Kutz $S$, Ebert AD, Kratz T, Wunderlich MT, et al. Temporal profile of release of neurobiochemical markers of brain damage after traumatic brain injury is associated with intracranial pathology as demonstrated in cranial computerized tomography. J Neurotrauma 2000;17:113-22.

34. Munck A, Guyre PM, Holbrook NJ. Physiological functions of glucocorticoids in stress and their relation to pharmacological actions. Endocr Rev 1984;5:25-44.

35. Waage A, Bakke O. Glucocorticoids suppress the production of tumour necrosis factor by lipopolysaccharidestimulated human monocytes. Immunology 1988;63: 299-302.

36. Danielson D, West MA. Recent developments in clinical management of surgical sepsis. Curr Opin Crit Care 2001;7:367-70.

37. Endo S, Inada K, Ceska M, Takakuwa T, Yamada $Y$, Nakae $\mathrm{H}$, et al. Plasma interleukin 8 and polymorphonuclear leukocyte elastase concentrations in patients with septic shock. J Inflamm 1995;45:136-42.

38. Metinko AP, Kunkel SL, Standiford TJ, Strieter RM. Anoxia-hyperoxia induces monocyte-derived interleukin8. J Clin Invest 1992;90:791-8.

39. Stanimirovic D, Satoh K. Inflammatory mediators of cerebral endothelium: a role in ischemic brain inflammation. Brain Pathol 2000;10:113-26.

40. Weiss SJ. Tissue destruction by neutrophils. N Engl J Med 1989;320:365-76. 
41. Anderson RE, Hansson LO, Nilsson O, Liska J, Settergren G, Vaage J. Increase in serum S100A1-B and S100BB during cardiac surgery arises from extracerebral sources. Ann Thorac Surg 2001;71:1512-7.

42. Pelinka LE, Toegel E, Mauritz W, Redl H. Serum S 100 B: a marker of brain damage in traumatic brain injury with and without multiple trauma. Shock 2003;19:195-200.

43. Pelinka LE, Szalay L, Jafarmadar M, Schmidhammer R, Redl H, Bahrami S. Circulating S100B is increased after bilateral femur fracture without brain injury in the rat. $\mathrm{Br}$ J Anaesth 2003;91:595-7.

44. Donato R. Functional roles of $\mathrm{S} 100$ proteins, calciumbinding proteins of the EF-hand type. Biochim Biophys Acta 1999;1450:191-231.
45. Barie PS. Neurologic dysfunction in the multiple organ dysfunction syndrome. J Trauma 1998;44:1108-9.

46. Schwarz $S$, Schwab $S$, Fabian CW, Schellinger $P$, Orberk E, Hund E. Infection: impaired consciousness as the initial symptom. Clinical and pathophysiologic aspects of septic encephalopathy. Nervenarzt 1997;68:292-7.

47. Bertsch T, Casarin W, Kretschmar M, Zimmer W, Walter S, Sommer C, et al. Protein S-100B: a serum marker for ischemic and infectious injury of cerebral tissue. Clin Chem Lab Med 2001;39:319-23.

Received November 16, 2004, accepted January 11, 2005 